\title{
Analysis of the Climatic Factors Influence on the Overhead Transmission Lines Reliability
}

\author{
Olga KONDRATEVA ${ }^{1}$, Ekaterina MYASNIKOVA², Oleg LOKTIONOV ${ }^{3 *}$ \\ ${ }^{1-3}$ Department of Engineering Ecology and Occupational Safety, National Research University «MPEI», \\ Moscow 111250, Russia
}

\begin{abstract}
In this study, the influence of climatic factors on overhead transmission lines reliability in Russia was discussed. A review of the possible impacts of climate change is provided. Using the example of an electric grid company providing electricity in the Republic of Bashkortostan some reliability targets associated with the impacts of weather events were calculated: the number of power outages, the failure rate of $1 \mathrm{~km}$ of overhead transmission lines and the outage time. From the calculations it was determined that these targets are at a quite high level, in particular for 6-10 kV overhead transmission lines. The main contribution is made by climatic factors wind and lighting storm. A correlation analysis of the overhead transmission lines outages as a function of the number of wind cases with a certain speed has shown a strong relationship between these characteristics. According to predictive information, the number of power outages in the territory under consideration in 2025 will increase by 1.5 times.
\end{abstract}

Keywords - Climate change; lighting storm; overhead transmission lines (OTL); power outages; precipitation; wind

\section{INTRODUCTION}

Providing a reliable, high-quality and safe power supply is an important task for electric grid companies. However, due to the large number of registered power outages, it is not always possible to achieve a stable power supply. To perform this task, it is necessary to maintain Unified Power Quality Index (UPQI) at an optimal level. It is difficult to do due to the high degree of physical depreciation of the electric energy system (EES) elements, considering the analysis of their technical condition.

Based on the accident data of power engineering facilities [1] and outage summary reports of various unified power system in Russia, it was concluded that the accident indices are at a high level. The most damaged elements are equipment with a voltage of $110 \mathrm{kV}$ or lower. Also, the most damaged and unreliable elements of system are overhead transmission lines (OTL).

A significant number of OTL outages is due to several facts. Firstly, they are very long elements of the electrical grid. Secondly, they are affected by a large number of factors. It can be constant factors that occur during a manufacture, installation, operation, etc. Also, it can be variable factors that include various climatic factors (wind loads, atmospheric overvoltages, ice loading), human factors (runover of vehicles on a support; throwing of wire, poor quality work on clearing and expanding a right-of-way, cutting of forest ranges), etc. In

* Corresponding author.

E-mail address: LoktionovOA@mpei.ru 
addition to the above reasons, the probability of an accident also depends on the season of the year: in the spring and summer seasons, the number of OTL outages increases due to thunderstorm activity and high temperatures; in the winter season it is increases due to the impact of solid precipitation.

It is interesting to note that the increasing impact of global climate change has recently led to increase emergencies, adverse events and outages in electrical grid companies [2]. A significant increase in dangerous hydrometeorological phenomena has been since 2003. These phenomena have caused significant damage to sectors of the economy and vital activity of the population. The following climatic factors have the most destructive effect: strong winds, heavy precipitation (snow, rain), hail, blizzards, abnormally cold weather in winter, fires, etc. [2].

In accordance with the annual reports of PAO Rosseti [3], a statistical analysis of outage summary reports in the Russian electric grid complex made it possible to estimate the percentage ratio of power outage reasons for OTL (insulated and non-insulated) and underground cables, as shown in Fig. 1.

Overhead transmission lines

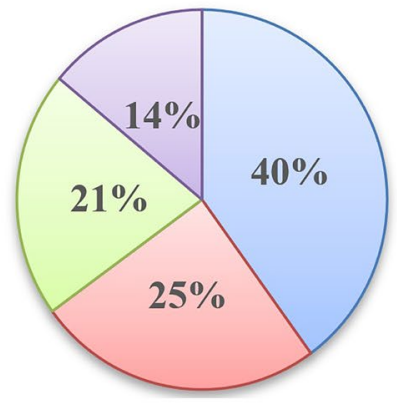

Underground cables

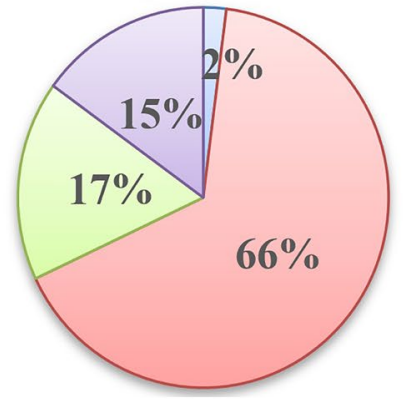

$\square$ Climatic load $\square$ Manufacturing and installing defects $\square$ External influences $\square$ Other reasons

Fig. 1 Percentage ratio of power outage reasons for OTL and underground cables in PAO Rosseti.

As can be seen OTL are significantly more affected by climatic loads than underground cables in Russia. For underground cables, accidents are mostly determined by technical factors. Therefore, when considering the impact of climatic factors in the energy sector, it is necessary to focus on OTL. At the same time, it is necessary to consider regional specifics of the area. It will help to more correctly identify the outage reasons and eliminate them in a timely manner.

The aim of this research is to determine the impact of climatic factors on OTL reliability targets and to develop a forecast of the wind effect (how one of the most destructive phenomena) on OTL reliability using the example of a specific region in Russia.

\section{Literature Review OF Climate Change ANd its EXPeCted ImPaCtS}

Extreme weather events were first among global risks on the planet in 2017 [4]. This goes to prove an increasing impact of climatic factors and their changes on life of society, in particular, in the energy sector.

According to the RCP scenarios developed by the IPCC, global climate change will lead to global air temperature anomalies of $1-4{ }^{\circ} \mathrm{C}$ by the end of the 21 st century [5]. An increase in 
air temperature will be observed throughout the country. For regions global warming will be various. However, we should expect an increase in average annual, winter and spring temperatures everywhere in the future [6]-[8].

Using regional models INMCM48 [9]-[11], RegCM4.5 [12]-[15], research by Russian scientists on numerical modelling of a hydrometeorological parameter wind in central part of Russia has shown that in the next 20-30 years there will be a decrease in the average annual relative wind speed by $0.05-0.15$, especially in areas with low wind loads. The outstanding feature of these models from global is that they take into account local characteristic of atmospheric circulation and consider the deviation of the parameters at a higher spatial resolution with reference to the analysis zone.

The upcoming warming will be much stronger for Russia than for the entire Earth, because Russia is located in a moderate and cold climate. There will be a significant change in precipitation, an increase in the frequency and intensity of various climate anomalies due to changes in atmospheric circulation [16]. According to [17], a temperature change of $1{ }^{\circ} \mathrm{C}$ will lead to an average increase in precipitation by $2 \%$ or approximately $20 \mathrm{~mm}$ per year throughout the Earth.

The impact of climate change in energy sector are already appearing. So, according to the accident data of some Russian energy companies [18], weather events led to a large number of outages in 2018: the percentage of such accidents was from 20 to $90 \%$ [18]. Examples of climatic factors and their impacts on the power supply system elements determined from the data [19], [20] and presented in Table 1.

\section{TABLE 1. Climatic FACTORS AND THEIR IMPACTS ON THE POWER SUPPLy SYSTEM ElEMENTS}

\begin{tabular}{lll}
\hline Climatic factors & Weak elements & Consequences impact \\
\hline $\begin{array}{l}\text { Extremely high } \\
\text { environment } \\
\text { temperatures }\end{array}$ & $\begin{array}{l}\text { OTL conductors, its contact } \\
\text { connections }\end{array}$ & $\begin{array}{l}\text { Overheat (OTL capability reduce), conductor tightness } \\
\text { reduce, sag and break, etc. When temperature increases, } \\
\text { probability of accidents initiation associated with sagging } \\
\text { conductors and short circuit increases too. }\end{array}$ \\
\hline Wind & $\begin{array}{l}\text { OTL conductors, its contact } \\
\text { connections, insulators }\end{array}$ & $\begin{array}{l}\text { Cross-whipping or loss of electrical connection, foreign } \\
\text { objects getting on OTL, falling trees, isolator damage and } \\
\text { break, OTL accessories weakening. }\end{array}$ \\
\hline $\begin{array}{l}\text { Lighting storm } \\
\text { OTL conductors, support and } \\
\text { insulators, surge protection } \\
\text { devices, protection devices }\end{array}$ & $\begin{array}{l}\text { Lightning stroke into a wooden support of OTL, and falling } \\
\text { out of hooks with insulators, surge protection device, surge } \\
\text { arrestor and insulators failure and break, }\end{array}$ \\
\hline $\begin{array}{l}\text { loading } \\
\text { OTL conductors, accessories, }\end{array}$ & $\begin{array}{l}\text { Conductor sag, cross-whipping or loss of electrical } \\
\text { connection, conductor galloping, insulators, support and } \\
\text { accessories wear break, short circuit. }\end{array}$ \\
\hline $\begin{array}{l}\text { Rain, rainfall (liquid } \\
\text { precipitations) }\end{array}$ & $\begin{array}{l}\text { OTL conductors, insulators, } \\
\text { disconnecting devices, RPAE }\end{array}$ & $\begin{array}{l}\text { Insulators failure or break, breakdown of fixing insulators, } \\
\text { moisture ingress into an OTL elements, relay protection and } \\
\text { automatics equipment (RPAE) failure, cross-whipping or } \\
\text { loss of electrical connection. }\end{array}$ \\
\hline $\begin{array}{l}\text { Dew and fog (liquid } \\
\text { precipitations) }\end{array}$ & $\begin{array}{l}\text { OTL conductors, support and } \\
\text { insulators }\end{array}$ & $\begin{array}{l}\text { Insulation failure due to condensation of atmospheric } \\
\text { precipitation on conductors, support, insulators, etc. }\end{array}$ \\
\hline $\begin{array}{l}\text { Contact connections of OTL } \\
\text { conductors, insulators, RPAE }\end{array}$ & $\begin{array}{l}\text { Conductor accessories wear, insulators failure or break, } \\
\text { RPAE failure, conductor galloping, cross-whipping or loss } \\
\text { of electrical connection, short circuit. }\end{array}$ \\
\hline
\end{tabular}

As you can see, the impact of climatic factors has a big role in society life. Therefore, timely and correct identification of power outages reasons and the forecast of climate change will help to avoid huge economic, technical, human and other losses in the future. 


\section{SELECTION OF THE TERRITORY FOR RESEARCH}

An analysis of the risk-based approach methodology in assessing of the OTL stability [21] as a probabilistic characteristic that determines normal power supply to consumers and similar researches [22]-[25] in the field of power grid reliability showed that traditional reliability targets such as SAIFI, SAIDI, EENS [26], LOLE, LOLH [27], [28] do not allow to fully evaluate and analyse the failure rate of power outages associated with climatic factors. These indices characterize the failure rate, the outage time without indicating the reason of accidents. Therefore, it was decided to evaluate the impact of climatic factors on reliability targets using the example of one region.

In this research, the territory of the Republic of Bashkortostan was selected as a pilot research zone to consider the impact of a specific type or group of weather events. This zone is characterized by a high distribution of dangerous phenomena that damage to the population and sectors of the economy [2]. For the operator (OOO Bashkirenergo) that provides power supply in the selected territory, according to the data [19], [20] the reasons for OTL outages were identified and further calculations were carried out.

As a result of the analysis of climatic factors that causes power outages, the following factors were systematized and selected [19], [20]: wind; lighting storm; precipitation and various concomitant factors; others.

The north and south parts of the territory of the Republic of Bashkortostan were identified for the study of climatic area. The north and south parts are divided in accordance with boundaries of power distribution zone (Fig. 2) [29] and based on zoning by wind pressure, ice wall thickness, standard values of minimum and maximum air temperature [30].

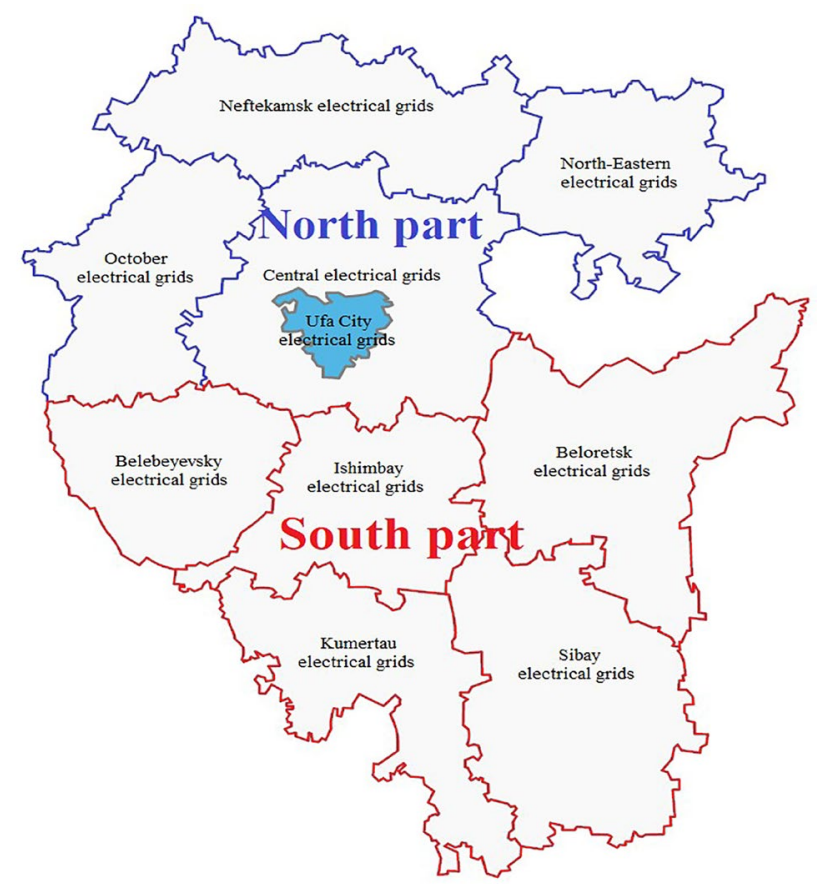

Fig. 2 Power distribution zone OOO Bashkirenergo. 


\section{Methods And Methodology}

With the view to study the impact of weather events on OTL reliability targets in the Republic of Bashkortostan, the following indices were determined: the total number of OTL outages and the failure rate of OTL associated with the impact of climatic factors, the outage time in specific incidents for the period from 2014 to 2018.

The methodological approach for determining the variation in the number of OTL outage incidents consisted of a sequential multi-stage analysis of statistical data from the operating logs of dispatch office personnel OOO Bashkirenergo for the period from 2014 to 2018 [19], [20]. The analysis structure included the identification of property's type and voltage level of the facility, the identification of outage reasons directly or indirectly related to climatic factors, and their classification into one or more of the following categories: wind loads, solid precipitation, liquid precipitation, thunderstorm activity, and climatic anomalies. The outage time was calculated based on the date and time of outage and also the date and time of electricity network map restoration to emergency state [19], [20] for a specific power outage. Those, the duration of OTL outage (in days) under the impact of specific climatic factors was calculated.

These data are of particular interest for the description of SAIFI and SAIDI indices, which can't be calculated directly due to the lack of data on the number of serving consumers.

When analysing structural reliability, which considers the composition of elements and their interworking, the average targets of similar elements (OTL, transformers, disconnector switches, busbar sections) are usually used: average failure rate, average repair rate, etc. [31].

The average failure rate of a particular OTL is determined by its length and average failure rate of $1 \mathrm{~km}$ of line. The last targets, considering the similarity of the elements (OTL) was calculated by the following formula [32]:

$$
\lambda_{0}=\frac{n_{0}}{L \cdot T}
$$

where $n_{0}$ is the total number of consumer power outages, $T$ is the observation time, which is equal to one considered year, $L$ is the total OTL length of the corresponding voltage class in $\mathrm{km}[33]$.

As mentioned earlier, one of the most destructive dangerous hydrometeorological phenomena is wind. Therefore, additional analysis was performed for the climatic factor wind. This analysis of wind at different speeds impact on OTL reliability targets consisted, firstly, in determining the total number of outages and outage time associated with the wind effects. Characteristics of the maximum wind speed at the moment of OTL power outages were obtained from the operating logs of dispatch office personnel [19], [20]. In the absence of these indicators in [19], [20], meteorological wind parameters for a specific incident were determined from statistical data for 3-hour time intervals of six weather stations that are evenly distributed over the area of the Republic of Bashkortostan [34]. The maximum wind speed averaged over a 10-minute time interval was used as the investigated parameter "wind speed". In this case, the wind speed characteristic from [34] was compared to an incident that was categorized as wind loads based on the date, time, and location of the power outage.

According to these indices, for the visual representation how wind impact on OTL reliability targets (in particular, on SAIFI and SAIDI), the following dependencies were calculated:

1. Dependence of the number of power outages caused by wind at different speeds in ranges of $5 \mathrm{~m} / \mathrm{s}$;

2. Dependence of the duration of outages (outage time) in the operation of the power 
supply system that occurred under the impact of wind at different speeds in ranges of $5 \mathrm{~m} / \mathrm{s}$, in hours per year.

The selected wind speeds range of $5 \mathrm{~m} / \mathrm{s}$ is considered in such a way that the first number of the range (half-interval) doesn't consider indices at a given wind speed, and the second number of the half-interval takes into account.

The second stage of wind analysis consisted in determining the correlation between the two indicators for the north and south parts of the Republic of Bashkortostan:

1. Number of OTL outages for all voltage classes that were categorized as wind loads at a certain wind speeds in the ranges of $5 \mathrm{~m} / \mathrm{s}$;

2. Number of recorded wind cases at a certain speed in the ranges of $5 \mathrm{~m} / \mathrm{s}$ in the territories corresponding to the boundaries of power distribution zone, according to the data of weather stations [34].

The methodological approach in this case was to classify all 3-hour time intervals based on the maximum wind speed averaged over a 10-minute time interval to category with a certain speed: $0-5,5-10,10-15,15-20,20-25,25-30,30-35,35-40 \mathrm{~m} / \mathrm{s}$. It was calculated by year and month.

Using the Pearson formula, the correlation coefficients for these two indicators were calculated by the two criteria for each speed range:

1. For total annual values for the period from 2014 to 2018 , i.e. the correlation between the total number of OTL outages under the impact of wind and the total number of recorded cases of wind speed by year was determined.

2. For average monthly values over five years. In this case, the correlation was determined in the same way as in the previous case, only the average monthly values were used instead of the total annual values. For this purpose, the corresponding correlation indicators were found by month for each of the five years, and then monthly arithmetic average values were determined.

The third stage of the wind analysis was to predict the wind speeds impact on OTL accident rate. The forecast included two sequential operations.

The first operation was to forecast the number of recorded wind cases at a certain speed in the ranges of $5 \mathrm{~m} / \mathrm{s}$ in the territories corresponding to the boundaries of power distribution zone, according to the data of weather stations [34]. For this, the number of such cases was calculated for each year between 2006 and 2019, and then a linear trend of these indicators is determined. The methodological approach for determining the number of recorded wind cases at a certain speed is the same as for calculating the second correlation indicator for 2014-2018.

According to the results of research [9]-[15], the regional models INMCM48 and RegCM4.5 describe climate changes with different levels of approximation for such a parameter as wind quite similarly. But the forecast values of the number wind cases at a certain speed in the range of $15 \mathrm{~m} / \mathrm{s}$ and more for the RegCM4.5 model are characterized by a small but increasing trend [14], [15]. The obtained linear trends of changes in the number wind cases for certain groups of wind speeds confirm the calculation of hydrometeorological parameters using regional models, and allow to predict potential changes for 3-5 years of the future with a certain degree of significance based on retrospective data. Therefore, the forecast was made until 2025 by extending the linear trends of the number of recorded wind cases at a certain speed in the ranges of $5 \mathrm{~m} / \mathrm{s}$ by years.

The second operation was to predict the number of OTL outages under the impact of wind at a certain speed. Those, the forecast was made for outages that were categorized as wind loads. For this, dependencies were built between the number of OTL outages and the number of wind cases in the region at a certain speed according to weather stations data from 2014 to 2018. These indicators were calculated earlier to determine the correlation. By constructing 
dependencies between these two indicators, their linear equation of connection (linear trend equations) were determined. Then, the predicted value of OTL outages was determined by substituting the predicted value of the number of recorded wind cases at a certain speed, which was calculated in the first operation of the forecast.

\section{RESUlts}

The total number of OTL outages under the impact of climatic factors on the territory of the Republic of Bashkortostan in the north and south parts is 1658 and 2157 cases annually, respectively, has a variable nature of change, but is at a high level [19], [20].

The average failure rate of $1 \mathrm{~km}$ of OTL $\left(\lambda_{0}\right)$, calculated by formula (3.1) according to the number of OTL outages assigned to the corresponding category of climatic impact, for the last five years (Fig. 3). Also, in Fig. 3, the curves show the duration of OTL power outages (in days) under the impact of corresponding climatic factors.

As can be seen, as a result of the impact of various climatic factors $\lambda_{0}$ is the highest in 2015 , and this indice has been growing annually since 2016 . Wind, lighting storm and precipitation together with other factors have a significant impact on OTL reliability.

According to Fig. 3, it can be noted that the greatest power outage time was recorded in 2014-2015. This is due to the fact that specialists of the company have introduced a set of measures aimed at improving the power supply reliability since 2016 .

The set of measures included technical re-equipment and reconstruction of energy facilities, timely de-icing, flood control, preparation of equipment for the thunderstorm season, etc. This phenomenon is considered when assessing the efficiency of compensatory measures and the stability of this equipment to the manifestation of climatic factors by calculating RR (relative risk) and OR (odds ratio) indices, as well as correction factors based on the wear degree of technological equipment.

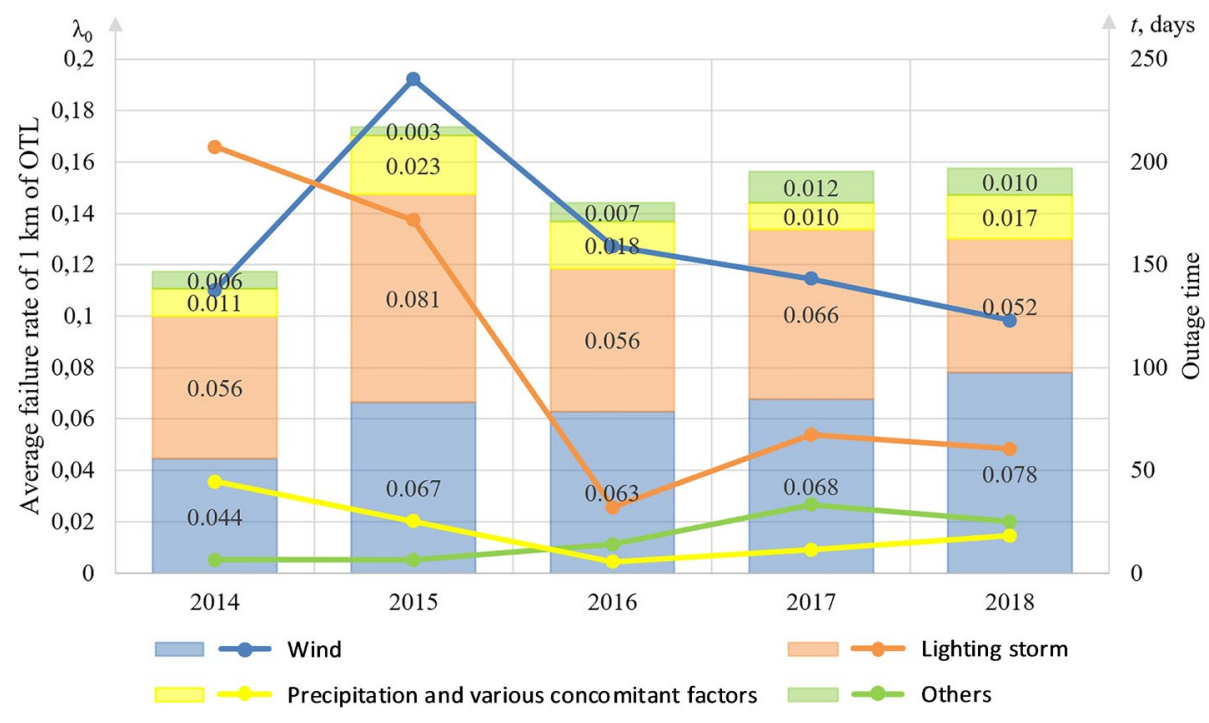

Fig. 3 The average failure rate of $1 \mathrm{~km}$ of OTL and OTL outage time (OOO Bashkirenergo) under the impact of the climatic factors from 2014 to 2018, where diagram area and curve are blue for wind, orange for lighting storm, yellow for precipitation and various concomitant factors, green for others climatic factors. 
The time of electrical power supply interruption due to OTL outages under wind impact significantly longer than OTL outage time under the lighting storm impact from 2015 to 2018. It can indicate an intensification and the effect of increasing lightning-surge proofness.

For the north and south parts of the Republic of Bashkortostan, $\lambda_{0}$ calculated from 2014 to 2018 by the total number of OTL outages caused by all categories of climatic factors, are presented in Table 2.

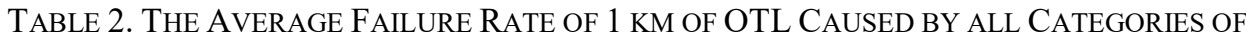
CLIMATIC FACTORS FROM 2014 TO 2018

\begin{tabular}{|c|c|c|c|c|c|c|}
\hline \multirow{2}{*}{$\begin{array}{l}\text { The territory of the } \\
\text { Republic of } \\
\text { Bashkortostan }\end{array}$} & \multicolumn{5}{|l|}{ Year } & \multirow{2}{*}{$\begin{array}{l}\text { Average } \\
\text { value for } \\
\text { five years }\end{array}$} \\
\hline & 2014 & 2015 & 2016 & 2017 & 2018 & \\
\hline North part & 0.061 & 0.045 & 0.068 & 0.078 & 0.076 & 0.069 \\
\hline South part & 0.056 & 0.129 & 0.076 & 0.077 & 0.082 & 0.091 \\
\hline
\end{tabular}

For the north part $\lambda_{0}$ has been increasing since 2015 (slightly decreasing in 2018 compared to 2017), for the south part $\lambda_{0}$ has been increasing since 2016. The average failure rate of $1 \mathrm{~km}$ of OTL prevails in the south part over five years (in the south of the region).

According to the results of a statistical analysis of outage summary reports [19], [20], it was determined that the main contribution to the total number of OTL outages with the climate impact category is made by $6-10 \mathrm{kV}$ overhead transmission lines, which account for $80.3-95.5 \%$ outages.

The average failure rate of $1 \mathrm{~km}$ of OTL for five years by voltage classes are presented in Table 3.

Table 3. The Average Failure Rate of 1 KM OF OTL by Voltage Class Over Five Years

\begin{tabular}{lllll}
\hline \multirow{2}{*}{$\begin{array}{l}\text { The territory of the Republic of } \\
\text { Bashkortostan }\end{array}$} & \multicolumn{4}{l}{ OTL voltage class, $\mathrm{kV}$} \\
\cline { 2 - 5 } & 0.4 & $6-10$ & 35 & 110 \\
\hline North part & 0.006 & 0.043 & 0.011 & 0.009 \\
South part & 0.011 & 0.055 & 0.012 & 0.012 \\
\hline
\end{tabular}

The highest $\lambda_{0}$ was recorded for $6-10 \mathrm{kV}$ OTL. In the south part of the Republic of Bashkortostan the average failure rate of $1 \mathrm{~km}$ of OTL of all voltage classes is higher than in the north part.

An additional analysis of the dynamics of changes in reliability targets for the climatic factor wind is presented below. The dependence of the number of OTL power outages under the wind impact at different speeds and the dependence of the total duration of outages in the operation of the power supply system under the wind impact at different speeds (in hours) are shown in Fig. 4, respectively. The dependences are obtained by accumulating data: in the case of the considered wind speeds range, the data of the previous wind speeds range are also considered. This is because the increase in wind speed increases accumulating outages. 


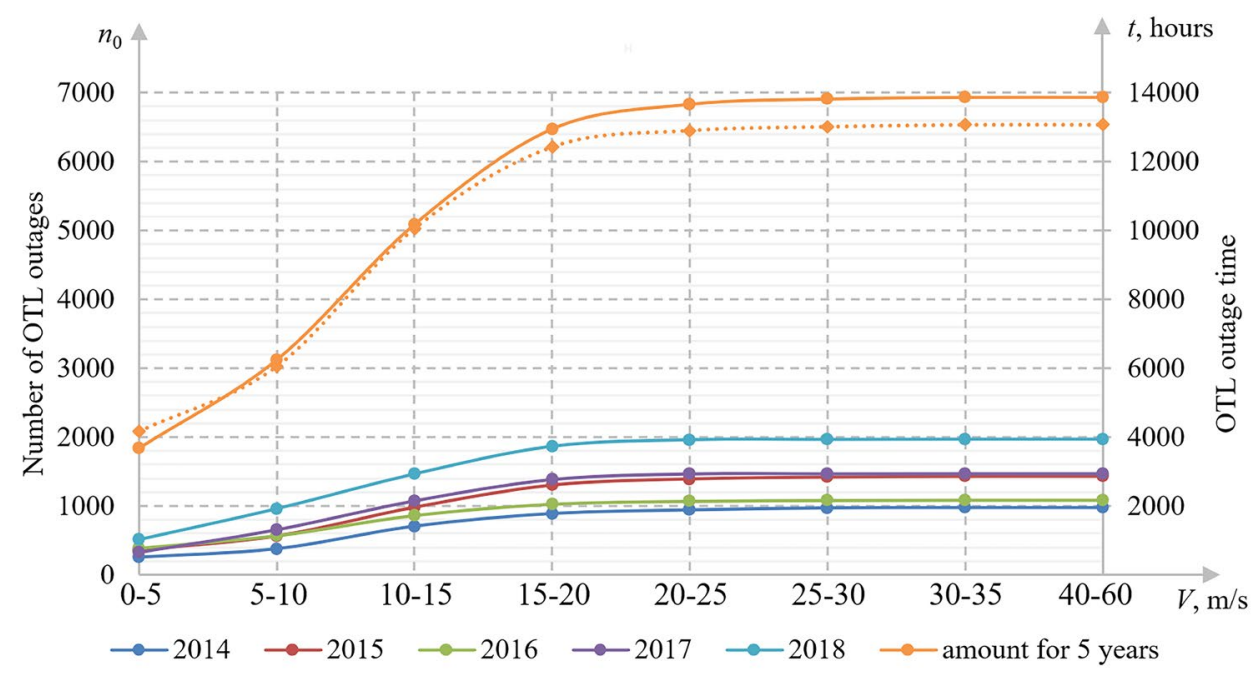

Fig. 4 Dependence of OTL outages number (solid line) under the wind impact at different speeds from 2014 to 2018 and OTL outage time in these incidents (dotted line) over the five years.

As can be seen from Fig. 4, the slope of the curves for all cases (from 2014 to 2018) shows the critical wind speeds for OTL are wind speeds up to and including $20 \mathrm{~m} / \mathrm{s}$. However, over the last three years under consideration, the increase in the slope of the curve at the wind speed range from $0-5$ to $15-20 \mathrm{~m} / \mathrm{s}$ is observed. It demonstrates an annual increase in OTL outage incidents at wind impact, in particular at wind impact in the ranges 5-10, 10-15, 15$20 \mathrm{~m} / \mathrm{s}$.

The increase in wind speed leads to the increase in the number of outages, which means the increase in SAIFI. However, the lower the value of this indice, the higher the level of reliability.

According to Fig. 4, it was determined that OTL outage time, which means the SAIDI indice is mainly determined by wind speeds up to $20 \mathrm{~m} / \mathrm{s}$. Thus, to increase the OTL reliability, it is necessary to consider the actions of wind from low speeds. So, for example, at wind speeds up to $5 \mathrm{~m} / \mathrm{s}$, there may be a cross-whipping or loss of electrical connection, a branch surge, an interphase short circuit, a pulldown insulator bundle with its next separation and other. The impacts of other wind speeds are similar, but the effect is stronger.

The correlation analysis for OTL of all voltage levels by the climatic factor wind, which was described in the chapter "Methods and Methodology", is presented below in Table 4. According to the two considered correlation criteria (total annual values and monthly average values over five years), a high positive correlation was observed in different cases.

\section{TABle 4. CorRelation COEFFICIENTS BetweEn the Number of OTL OUtAGES AND Wind SPEED IN THE RANGE OF $5 \mathrm{M} / \mathrm{s}$}

\begin{tabular}{|c|c|c|c|c|c|c|c|}
\hline \multirow{2}{*}{$\begin{array}{l}\text { The territory of } \\
\text { the Republic of } \\
\text { Bashkortostan }\end{array}$} & \multirow{2}{*}{ Parameter to analyse } & \multicolumn{6}{|c|}{ Wind speed, $\mathrm{m} / \mathrm{s}$} \\
\hline & & $0-5$ & $5-10$ & $10-15$ & $15-20$ & $20-25$ & $25-30$ \\
\hline North part & Total annual values & 0.723 & 0.679 & 0.822 & 0.878 & 0.467 & 0.342 \\
\hline South part & $\begin{array}{l}\text { Monthly averages over five } \\
\text { years }\end{array}$ & 0.441 & - & 0.525 & 0.730 & 0.431 & 0.449 \\
\hline
\end{tabular}


In the case for the north part of the Republic of Bashkortostan, a positive correlation was recorded for the criterion "total annual values" and was absent for the criterion "monthly average values over five years". For the north part it is opposite. It means that the annual increase (decrease) in the total annual number of recorded wind speed cases in the north part increases (decreases) in the total annual number of OTL outages at a given wind speed. Thus, the annual OTL accident rate due to wind impact is closely related to the annual indicators of meteorological wind parameters in the north of the territory under consideration. In the case of the south part of the Republic of Bashkortostan, the sum of OTL outages at a certain wind speed is related to the monthly average number of wind speed cases. Those, the structure of the monthly distribution of OTL accident rate that were categorized as wind loads largely repeats the distribution of monthly average meteorological wind parameters in the south.

For the south part, when analysing monthly averages over five years, a positive correlation was recorded for all cases, except for wind speed of $5-10 \mathrm{~m} / \mathrm{s}$.

The obtained correlation coefficients are the most uniform in the case of 6-10 kV OTL. For voltage classes $0.4,35$, and $110-\mathrm{kV}$, the correlation between outages and wind speed is different in most cases. For voltage classes 35 and $110 \mathrm{kV}$, this is due to the small number of OTL outages at the appropriate wind speed. Mainly depending on the year and wind speed at which the outage occurred, the number of incidents is less than 3-4 cases. For voltage class $0.4 \mathrm{kV}$, this is due to a small data sample, because the $0.4 \mathrm{kV}$ OTL outages have been recorded in operating logs [19], [20] since 2017.

In order to increase the reliability and reduce the lines accident rate, special attention was paid to the climatic factor wind in the conditions of climatic changes and the wind forecast was made for the region. The forecast of the number of recorded wind cases at a certain speed in the ranges of $5 \mathrm{~m} / \mathrm{s}$ [34] until 2025 is presented in Fig. 5.

Basically, the number of wind cases at a certain speed have tendency to increase in the region. According to forecasts, it is planned to reduce the average annual wind speed of 5$10 \mathrm{~m} / \mathrm{s}$ throughout the territory by 2025 .

According to the results of the wind speeds forecast, OTL accident rate was predicted. In the context of predictive information of a decrease in the number of recorded wind cases at a certain speed, it was determined that:

3. For the south part:

- In the case of wind speed of $0-5 \mathrm{~m} / \mathrm{s}$, the number of OTL outages will decrease by about $1 \%$ to the end $2025 \mathrm{t}$ can be assumed that the number of power outages will remain at the same level;

- In the case of wind speed of 5-10 m/s, there is predicted a sharp decrease the wind cases with a given speed up to negative values. Therefore, it was decided to make a meteorological data sample from 2013. In this case, the number of power outages will remain at the same level by 2025 .

4. For the north part:

- In the case of wind speed of $5-10 \mathrm{~m} / \mathrm{s}$, the number of OTL outages will decrease by about $1.4 \%$;

- In the case of wind speed of 20-25 m/s, the number of OTL outages will remain at the same level. 


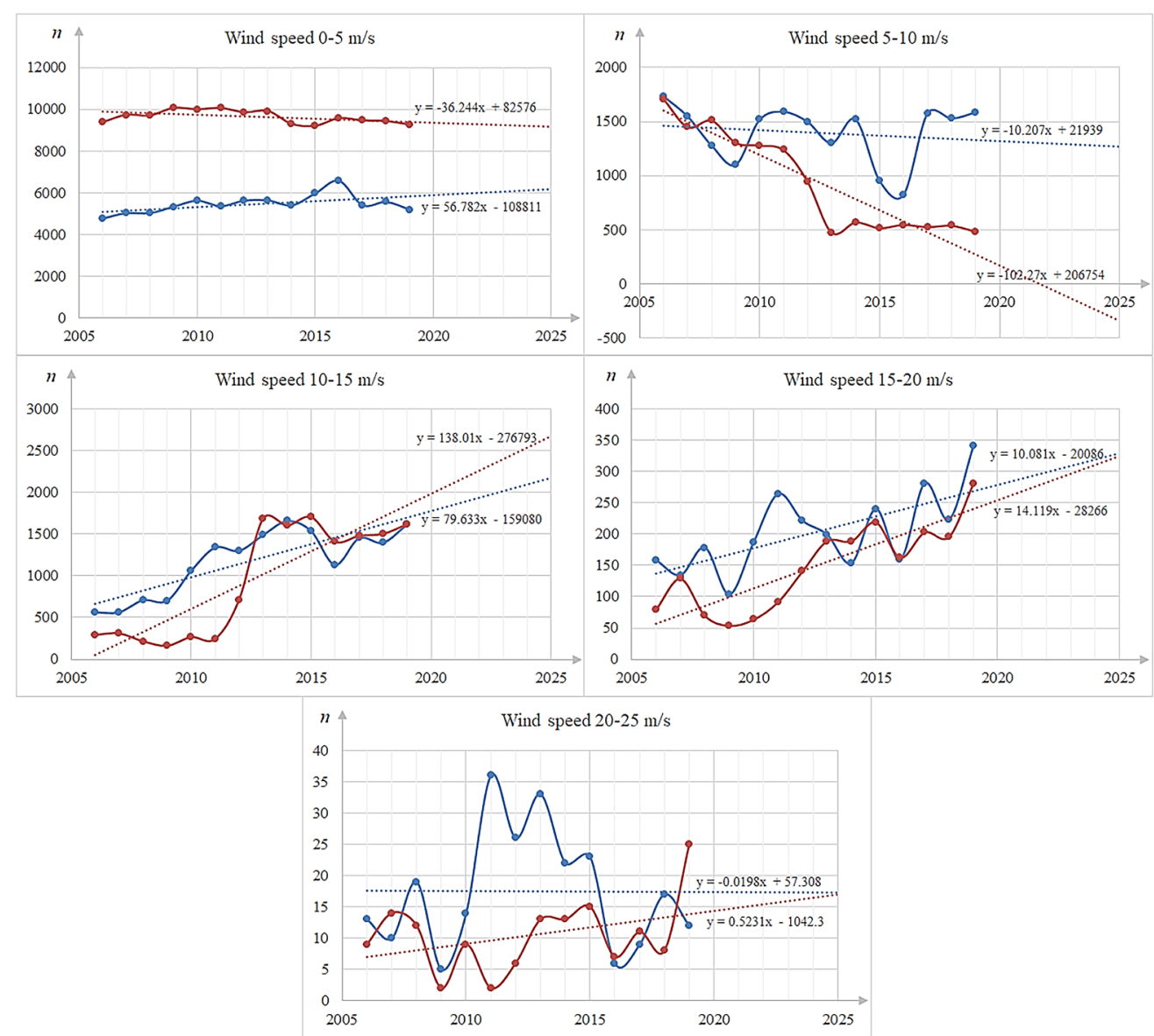

Fig. 5. The number of recorded wind cases at a certain speed in the Republic of Bashkortostan from 2006 to 2025 , where the blue curves are the north part, the red curves are the south part.

The most drastic consequences of wind speed changes in the region will be observed when the annual wind speed increases. So, for example, according to forecasts an increase in the average annual wind speed of $0-5 \mathrm{~m} / \mathrm{s}$ in the north part of the region will increase the number of OTL outages by about $166 \%$ (outages will be in 2.7 times more), at wind speeds of $10-15 \mathrm{~m} / \mathrm{s}$ it will increase by about $50 \%$ (in 1.5 times more), at wind speeds of $15-20 \mathrm{~m} / \mathrm{s}$ it will increase by about $74 \%$ (in 1.7 times more).

According to predictive information an increase in the average annual wind speed of $10-15 \mathrm{~m} / \mathrm{s}$ in the south part will increase the number of power outages by about $104 \%$ (outages will be in 2 times more), at wind speed of $15-20 \mathrm{~m} / \mathrm{s}$ it will increase by about $68 \%$ (in 1.7 times more), at wind speed of $20-25 \mathrm{~m} / \mathrm{s}$ it will increase by about $51 \%$ (in 1.5 times more) by 2025 .

According to forecasts for 2025, an increase in the total number of OTL outages in the north part of the Republic of Bashkortostan will be about $66 \%$, in the south part it will be about $43 \%$. Moreover, in the south part the number of power outages will prevail. An increase in power outages throughout the Republic of Bashkortostan will be about $53 \%$. 


\section{CONCLUSION}

Climatic factors have a great influence on OTL accident rate. Using the example of the company that provides power supply in the Republic of Bashkortostan, the most significant climatic factors were identified, like wind and lighting storm. They have a big impact on reliability targets: a total number of outages, a failure rate and outage time. In determining outage time, it is necessary to consider a large number of indicators: the electricity network map, category of electrical energy consumers, presence of disconnector switches, automatic transfer switch (ATS), RPAE, terrain appreciation, efficiency of the work by field service team. However, despite the need to consider such a large number of factors, the outage time under the impact of wind and lighting storm still remains at a significant level.

An additional analysis of the climatic factor wind showed a strong correlation between OTL outages and climatic data of meteorological service on wind speed in the Republic of Bashkortostan. It means that it is necessary to carry out measures to reduce the impact of this natural phenomenon.

According to predictive information the total wind potential of the region under consideration will change slightly by the middle of the 21 st century [35]. However, in conformity with the regional meteorological data, it was determined that a change in certain wind speed will lead to the fact that in 2025 the number of OTL outages under the impact of wind will increase by about $53 \%$ throughout the territory. The total number of OTL power outages in the north of the region will increase by about $66 \%$, in the south by about $43 \%$. The main contribution in the north part will be made by winds at a speed of $0-5,10-15$, $15-20 \mathrm{~m} / \mathrm{s}$, in the south part will be made by winds with a speed of $10-15 \mathrm{~m} / \mathrm{s}$ and higher.

Predictive information of OTL accident rate can be obtained by studying long-term changes of different climatic factors for certain regions of the country. It will allow not only to prevent or reduce the number of such dangerous situations in a timely manner in the future, but also to increase the efficiency of maintenance and the service life of equipment, to reduce costs of the electric power dissipation and costs for replacement electrical equipment, to improve recovery by personnel and conditions of workers' protection in energy industry, etc.

\section{ACKNOWLEDGEMENT}

This work has been supported by the Russian Science Foundation within the project "Adaptation potential of Russian energy system towards the modern technological challenges under the climate change" No. 18-79-10255

\section{REFERENCES}

[1] Ministry of Energy. Informacija ob avarijnosti v elektrosetjah i generacii (The accident rate of power engineering facilities) [Online]. [Accessed 10.10.2018]. Available: https://minenergo.gov.ru/node/267 (in Russian)

[2] Rosgidromet. Ezhegodnie dokladi o sostojanii klimata (Annual climate reports) [Online]. [Accessed 20.07.2019]. Available: http://climatechange.igce.ru/index.php?option=com_docman\&Itemid=73\&gid=27\&lang=ru (in Russian)

[3] Godovie otcheti PAO ROSSETI (Annual reports of PAO ROSSETI), 2010-2018 [Online]. [Accessed 01.07.2019]. Available: https://rosseti.ru/investors/info/year/ (in Russian)

[4] Kattsov V. M. et al. Doklad o klimaticheskih riskah na territorii Rossijskoj Federacii (Report on climate risks in the Russian Federation). St. Petersburg: Roshydromet, 2017. (in Russian)

[5] Kislov A. V. Klimatologija s osnovami meteorologii (Climatology with the basics of meteorology). Moscow: Publishing Center Academy, 2016. (in Russian)

[6] Klimenko V. V. Universaljnaja I globaljnaja istorija (evolucija Vselennoj, Zemli, zhizni I obschestva) (Universal and global history. Evolution of the Universe, Earth, Life, Society: Reader.). Volgograd: Uchitel, 2012. (in Russian) 
[7] Klimenko V. V. et al. Climate change and dynamics of the permafrost in Northwestern Russia with the next 300 years. Earth's Cryosphere 2007:11(3):3-13.

[8] Klimenko V. V., Tereshin A. G., Mikushina O. V. Izmenenija klimaticheskoh parametrov I ih rolj v rabote system teplosnabzhenija strain (Change of climatic parameters and their role in the operation of the country's heat supply systems). News of heat supply 2008:8:5-13. (in Russian)

[9] Volodin E. M., Dianskii N. A., Gusev A. V. Simulating present-day climate with INMCM 4.0 coupled model of the atmospheric and oceanic general circulations. Izvestiya, Atmospheric and Oceanic Physics 2010:46:448-466. https://doi.org/10.1134/S000143381004002X

[10] Volodin E. M. The nature of 60-year oscillations of the Arctic climate according to the data of the INM RAS climate model. Russian Journal of Numerical Analysis and Mathematical Modelling 2018:33:359-366. https://doi.org/10.1515/rnam-2018-0031

[11] Volodin E. M., et al. Simulation of the modern climate using the INM-CM48 climate model. Russian Journal of Numerical Analysis and Mathematical Modelling 2018:33:367-374. https://doi.org/10.1515/rnam-2018-0032

[12] Titov A. V., Khoperskov A. V. Verifikacija regionaljnoj klimaticheskoj modeli RegCM V4.5 dlja Nizhnej Volgi (Verification of the Regional climate model RegCM v4.5 for the Lower Volga). Inform. technology and nanotechnology 2019:278-283. (in Russian)

[13] Klikunova A. Yu., Khoperskov A. V. Numerical hydrodynamic model of the Lower Volga. IOP Conf. Series: Journal of Physics: Conf. Series 1128 2018:1-6. https://doi.org/10.1088/1742-6596/1128/1/012087

[14] Titov A. V., Khoperskov A. V. Regional Climate Model for the Lower Volga: Parallelization Efficiency Estimation. Supercomputing Frontiers and Innovations 2018:5:107-110. http://dx.doi.org/10.14529/jsfi180413

[15] Khoperskov A. V., et al. Razvertivanie regionaljnoj klimaticheskoj modeli dlja Juga Rossii na osnove RegCM 4.5 (Deployment of the regional climate model for the south of Russia based on RegCM4.5). Mathematical Physics and Computer Simulation 2019:22:68-95. https://doi.org/10.15688/mpcm.jvolsu.2019.3.6 (in Russian)

[16] Klimenko V. V. Energija, Priroda i Klimat (Energy, nature and climate). Moscow: Publishing House MPEI, 1997. (in Russian)

[17] Klimenko V. V., Fedotova E. V. Gidroenergetika Rossii v uslovijah globaljnih izmenenij klimata (Hydropower of Russia in the context of global climate change.). Reports of the Academy of Sciences 2019:484:156-160. https://doi.org/10.31857/S0869-56524842156-160 (in Russian)

[18] Kondrateva O. E., et al. Dijavlenie klimaticheskih faktorov, vlijajuschih na nadezhnostj vozdushnih linij peredachi (Identification of climatic factors affecting the reliability of overhead lines). Proceedings of the Quality Management at the stages of the life cycle of technical and technological systems 2019:1:373-377. (in Russian)

[19] Annex №1. Information about the technical position of the electrical grid OOO Bashkirenergo [Online]. [Accessed 20.11.2018]. Available: https:/www.bashkir-energo.ru/consumers/standards-disclosure/

[20] OOO "Bashkirenergo". Prilozhenie 1. Svedenija o tehnicheskom sostojanii setej OOO "Bashkirenergo" (Annex №1. Information about the technical position of the electrical grid OOO Bashkirenergo) [Online]. [Accessed 20.11.2018]. Available: https://www.bashkir-energo.ru/consumers/standards-disclosure/arkhiv-dokumentov-utrativshikh-silu/

[21] CIGRE. Guidelines for the management of risks associated with severe climate conditions and climate change in relation to air lines. Technical brochure. CIGRE, 2014:598.

[22] Dupin R., Kariniotakis G., Michiorri A. Overhead lines Dynamic Line rating based on probabilistic day-ahead forecasting and risk assessment. International Journal of Electrical Power \& Energy Systems 2019:110:565-578. https://doi.org/10.1016/j.ijepes.2019.03.043

[23] Arab A., Tekin E., Khodaei A. System Hardening and Condition-Based Maintenance for Electric Power Infrastructure Under Hurricane Effects. IEEE Transactions on Reliability 2016:65:1457-1470. https://doi.org/10.1109/TR.2016.2575445

[24] Loktionov O. A., et al. Analysis of Dangerous Wind Loads Influence on 110-220 kV Power Grid Reliability in Yamalo-Nenets Autonomous District of Russian Federation. International Youth Conference on Radio Electronics, Electrical and Power Engineering (REEPE) 2020:1-6. https://doi.org/10.1109/REEPE49198.2020.9059204

[25] Rezaei S. N., et al. Analysis of the effect of climate change on the reliability of overhead transmission lines. Sustainable Cities and Society 2016:27:137-144. https://doi.org/10.1016/j.scs.2016.01.007

[26] IEEE. IEEE guide for electric power distribution reliability indices (IEEE Std. 136-2012). IEEE, 2012. http://doi.org/10.1109/IEEESTD.2012.6209381

[27] NERC Standard BAL-502-RF-03 «Planning Resource Adequacy Analysis, Assessment and Documentation» [Online]. [Accessed 10.03.2020]. Available: https://www.nerc.com/pa/Stand/Reliability\%20Standards/BAL-502-RF-03.pdf

[28] Directive 2019/944/EU of the European Parliament and of the Council of 5 June 2019 on common rules for the internal market for electricity and amending Directive 2012/27/EU. Official Journal of European Union 2019: L 158/125.

[29] OOO Bashkirenergo. Production department [Online]. [Accessed 20.11.2018]. Available: https://www.bashkirenergo.ru/index.php (in Russian)

[30] SP 20.13330.2016 Nagruzki I vozdejstvija. Aktualizirovannaja redakcija SNiP 2.01.07-85* (c Izmenenijami N 1, 2) (SP 20.13330.2016 Loads and impacts. The updated edition of SNiP 2.01.07-85* (with Amendments № 1, 2).). [Online]. [Accessed 25.11.2019]. Available: http://docs.cntd.ru/document/456044318 (in Russian) 
[31] Aguzarov A. V., et al. Raschet pokazatelej nadezhnosti elementov elektroenergeticheskoj sistemi naprjazheniem 110 $\mathrm{kV}$ (Calculation of reliability targets of elements of the electric power system with a voltage of $110 \mathrm{kV}$.). Energy and resource saving. Power supply. Unconventional and renewable energy sources. Atomic energy: materials of Danilov readings. 2018:52-55. (in Russian)

[32] Uteuliev B. A., Tarasov A. G. Resurs opor vozdushnih linij elektroperedachi (Life time of overhead transmission line supports). Scientific Bulletin of NSTU 2015:59:89-97. https://doi.org/10.17212/1814-1196-2015-2-89-97 (in Russian)

[33] Saratov D. V. O podgotovke k prohozhdeniju OZP 2017-2018g. v elektricheskih setjah dochernih obschestv AO "BESK" (About the preparation for the autumn-winter period 2017-2018 in AO BESK). Bashkortostan: BESK, 2018. (in Russian)

[34] Weather in Bashkortostan [Online]. [Accessed 20.11.2018]. Available: https://rp5.ru/Погода_в_Башкортостане (in Russian)

[35] Klimenko V. V., Tereshin A. G., Fedotova E. V. Rost potenciala vozobnovljaemih istochnikov energii v Rossii v uslovijah globaljnogo poteplenija (Increase in renewable energy potential in Russia due to clobal warming). Scientific and technical Bulletin of SPBPU. Natural and engineering Sciences 2019:25:6-27. https://doi.org/10.18721/JEST.25301 (in Russian) 